\title{
PERAN PEREMPUAN DAYAK KANAYATN DALAM TRADISI UPACARA NAIK DANGO (STUDI DI DESA PADANG PIO KECAMATAN BANYUKE HULU KABUPATEN LANDAK KALIMANTAN BARAT)
}

\author{
Priani Wina* \\ Novi Triana Habsari*
}

\begin{abstract}
Abstrak
Penelitian ini bertujuan untuk mengetahui peran perempuan Dayak Kanayatn dalam tradisi upacara Naik Dango di Desa Padang Pio Kecamatan Banyuke Hulu Kabupaten Landak Kalimantan Barat, baik itu pada waktu persiapan maupun pelaksanaan upacara Naik Dango. Lokasi penelitian ini adalah di Desa Padang Pio Kecamatan Banyuke Hulu Kabupaten Landak Kalimantan Barat. Penelitian ini merupakan penelitian kualitatif yaitu sebuah penelitian yang datanya tidak berbentuk angka dan biasanya menekankan untuk memahami dan menafsirkan makna suatu peristiwa interaksi tingkah laku manusia. Jenis penelitian yang digunakan yaitu jenis studi kasus. Teknik pengambilan sampel yaitu menggunakan snowball sampling (bola salju) yaitu dari masyarakat biasa 3 koresponden, perangkat Desa 4 koresponden (pengurus adat, pengacara adat, imam adat, dan kepala adat/kepala desa), dan Dinas Pariwisata Kabupaten Landak 1 koresponden. Pengumpulan data menggunakan metode wawancara, observasi dan dokumentasi. Analisis data menggunakan metode reduksi data, penyajian data (display data) dan penarikan kesimpulan (verifikasi). Validasi yang digunakan yaitu menggunakan trianggulasi sumber.

Berdasarkan hasil penelitian diketahui bahwa peran perempuan Dayak Kanayatn dalam Tradisi upacara Naik Dango tersebut, pelaku utama dalam persiapan maupun pelaksanaannya adalah laki-laki, sedangkan perempuan hanya selaku pelaku kedua. Dalam mempersiapkan bahan-bahan Nyangahatn (roba atau plantar) untuk ritual upacara Naik Dango, sedangkan pada saat pelaksanannya perempuan sebagai penari baik itu seni tarian Nimang Padi, Ngantar Panompo dan seni tarian Jonggan. Tradisi Upacara Naik Dango merupakan upacara adat Dayak Kanayatn. Peran perempuan dalam upacara tersebut karena sesuai adat yang mewajibkannya. Dalam upacara adat tersebut perempuan memiliki peran fungsional baik persiapan maupun pelaksanaannya. Jika Tradisi Naik Dango tidak dapat terlaksanakan maka akan terjadi bencana.
\end{abstract}

Kata Kunci: Upacara Naik Dango, Peran Perempuan Dayak

\section{Pendahuluan}

Keragaman budaya adalah keniscayaan yang ada di bumi Indonesia. Keragaman pun dapat menyatukan suatu perbedaan kebudayaan yang ada di Indonesia. Kebudayaan adalah keseluruhan sistem gagasan, tindakan dan hasil karya manusia dalam kehidupan masyarakat yang dijadikan milik diri manusia dengan belajar (Koentjaraningrat, 2009: 144).
Keragaman budaya Indonesia adalah sesuatu yang tidak dapat dipungkiri keberadaannya. Menurut Esten (dalam Hanif 2014: 23) aset budaya yang tersebar di seluruh wilayah Indonesia memberi nuansa keanekaragaman corak adat dan tradisi yang ada di wilayah tersebut. Tradisi lahir dari kebiasaan yang dilakukan oleh anggota masyarakat terdahulu kemudian

* Priani Wina adalah Alumni Mahasiswa Pendidikan Sejarah UNIVERSITAS PGRI MADIUN

* Novi Triana Habsari adalah Dosen Prodi Pendidikan Sejarah UNIVERSITAS PGRI MADIUN 
ditirukan dan dilakukan oleh generasi berikutnya.

Kebudayaan yang dimiliki oleh setiap masyarakat itu tidak sama, seperti di Indonesia yang terdiri dari berbagai macam suku bangsa yang berbeda, tetapi setiap kebudayaan mempunyai ciri dan sifat yang sama (Elly dkk 2007: 33). Berbagai macam perbedaan jenis suku yang ada di Indonesia membawa keragaman kebudayaan tersendiri dari berbagai kebudayaan yang di miliki oleh setiap pulau dengan kegiatan upacara adat.

Upacara adat merupakan salah satu bentuk kebudayaan yang berkaitan dengan berbagai fungsi, sehingga mempunyai arti yang sangat penting bagi kehidupan di masyarakat (Saryana, dkk 2003: 1). Tradisi upacara Naik Dango memiliki sejarah yang menarik dimana tradisi Naik Nango didasari mitos asal mula padi menjadi populer dikalangan masyarakat Dayak yakni cerita Nek Baruang Kulup (Ivo 2001: 293).

Tradisi Naik Dango diawali dari ceita nenek moyang yaitu cerita Nek Barung Kulup. Dalam cerita Nek Baruang Kulup ini menjadi jelas bahwa pekerjaan dan kehidupan seperti bertani, berladang, kelahiran, perkawinan dan kematian dilakukan dengan mengikuti aturan-aturan berdasarkan saling menghormati antara dan ketiga kumunitas tadi (Rufinus 2014: 43). Seperti halnya dengan tradisi upacara Naik Dango di Desa Padang Pio Kecamatan Banyuke Hulu Kabupaten Landak
Kalimantan Barat. Masyarakat Desa Padang Pio mempercayai bahwa lingkungan hidup perlu dilestarikan dengan cara ritual atau tradisi keagamaan yang mengandung nilai kearifan lokal.

Tradisi upacara Naik Dango membutuhkan banyak hal yang perlu dipersiapkan. Dalam kegiatan persiapan tersebut tidak hanya dilakukan oleh kaum laki-laki saja, tetapi kaum perempuan juga ikut melakukan banyak persiapan. Misalnya berkaitan dengan persiapan kegiatan Nyangahatn manta (bahan yang masih mentah) dan nyangahat masak (bahan yang sudah masak).

Selain mempersiapkan bahan perlengkapan upacara, perempuan Dayak difungsikan juga sebagai penari dalam pembukaan sampai penutup acara. Peran perempuan Dayak Kanayatn dalam hal ini sangat diperlukan demi lancarnya upacara yang dilaksanakan. Hal ini karena kaum perempuan dianggap sebagai seseorang yang lebih ahli atau mampu dalam memasak atau yang berkaitan dengan masalah dapur. Tradisi upacara Naik Dango merupakan tradisi yang tak bisa dilepaskan dari peran kaum perempuan dalam persiapan maupun pelaksanaannya.

Namun seiring perkembangan jaman, perempuan Dayak masa kini harus tampil menjadi figur yang penting di tengahtengah masyarakat. Partisipasi aktif dalam usaha memajukan berbagai bidang kehidupan yang mana tidak kalah 
kualitasnya dengan hasil kerja kaum lakilaki. Contohnya dalam kemajuan budaya, pendidikan, ekonomi, sosial maupun teknologi dengan demikian perempuan Dayak tidak di pandang rendah oleh kaum laki-laki.

Tradisi upacara Naik Dango, peran kaum perempuan Dayak sangat penting, sehingga keberadaan mereka tidak dipandang sebelah mata dan sangat dibutuhkan oleh pihak lain. Untuk itu, penelitian tentang peran perempuan Dayak Kanayatn dalam tradisi upacara Naik Dango di Desa Padang Pio Kecamatan Banyuke Hulu Kabupaten Landak Kalimantan Barat menarik untuk diteliti.

\section{Tujuan Penelitian}

Adapun tujuan penelitian ini adalah untuk mengetahui peran perempuan Dayak Kanayatn dalam tradisi upacara Naik Dango di Desa Padang Pio Kecamatan Banyuke Hulu Kabupaten Landak Kalimantan Barat.

\section{Kajian Pustaka}

\section{Pengertian Upacara Naik Dango}

Dalam masyarakat Dayak Kanayatn di kenal dengan tradisi upacara Naik Dango. Istilah Dayak pada berbagai kelompok masyarakat di Kalimantan Barat terdapat berbagai variasinya, yaitu Daya, Dayo, Dayo, dan Dayuh yang berarti "Hulu" dan "Manusia" dan ada juga artinya "Darah" (Alloy, dkk 2008: 9).

Kamus Antropologi (1985: 423), menjelaskan upacara merupakan suatu kegiatan pesta tradisional yang diatur menurut tata adat atau hukum yang berlaku dalam masyarakat dalam rangka memperingakati peristiwa penting atau lain-lain dengan ketentuan adat yang bersangkutan.

Seperti dalam masyarakat suku Dayak Kanayatn pada umumnya tidak bisa lepas dengan upacara adat yang sangat dilestarikan oleh masyarakat Dayak. Salah satunya adalah upacara Naik Dango. "Dango" dalam bahasa Dayak Kanayatn yang berarti "Lumbung" yaitu tempat atau gudang untuk menyimpan padi. Dalam Kamus Bahasa Dayak Kanayatn (2011: 53) "Dango" yang berarti "Dangau" atau lumbung padi.

Naik Dango merupakan penutupan dari rangkaian upacara yang berkaitan dengan kegiatan berladang khususnya tanam padi, serta sebagai tanda bahwa kegiatan perladangan telah selesai dilaksanakan. Upacara Naik Dango bertujuan sebagai ungkapan rasa syukur masyarakat kepada Jubata (Sang pencipta) atas panen padi yang diperoleh (Widyanto dkk, 1997: 73).

\section{Fungsi Upacara Naik Dango}

Menurut Sri Mintosih, dkk (1997: 73), fungsi upacara Naik Dango adalah sebagai ungkapan rasa syukur masyarakat kepada Jubata (Sang Pencipta) atas panen padi yang telah di peroleh. Pendapat Bahri (dalam Ivo 2001: 293-294) upacara Naik Dango mempunyai fungsi : 
a. Menyukuri karunia Jubata (Sang Pencipta)

b. Mohon restu kepada Jubata (sang Pencipta) untuk menggunakan padi yang telah disimpan di Dango.

c. Pertanda penutupan tahun berladang.

d. Mempererat hubungan persaudaraan/solidaritas.

\section{Peran Perempuan}

Perbedan gender telah melahirkan ketidak adilan gender yang berimbas pada posisi yang disandang oleh kaum perempuan (Sugihastuti, 2007: 279). Pembicaraan mengenai perempuan telah mengalami pergeseran yang cukup mendasar pada saat konsep "gender" digunakan sebagai perspektif.

Konsep "perempuan" yang digunakan sebelumnya, cenderung mengisolasi perempuan dari laki-laki sehingga yang diperhatikan lebih kepada "sistem" dimana perempuan mengambil peran (Irwan Abdullah, 2001:23). Dari pendapat di atas, maka gender merupakan perbedaan antara laki-laki dan perempuan. Perbedaan tersebut tidak membuat kaum perempuan diposisikan atau kurang difungsikan dalam masyarakat justru perempuan memiliki peran yang sangat penting.

Peran serta perempuan dalam kehidupan sosial budaya di dalam masyarakat itu cukup besar. Terlebih lagi setelah munculnya gerakan transformasi feminisme yang bertujuan untuk mengangkat kedudukan perempuan agar sejajar dengan kaum laki-laki. Gerakan ini berusaha untuk memecahkan masalah kaum perempuan dengan cara menyiapkan kaum perempuan agar bisa bersaing dalam dunia yang penuh persaingan bebas (Fakih, 2007: 82).

Husain Haikal (2012: 45) menjelaskan bahwa perempuan dan gerakannya telah lahir jauh sebelum kemerdekaan RI. Kegiatan pergerakan perempuan terus berjalan hingga mencapai puncaknya pada tahun 1965. Bersama dengan itu, bermunculan juga berbagai organisasi "keras" perempuan bergabung dalam Lembaga Swadaya Masyarakat (LSM).

Seperti kebudayaan lain, Jawa juga menempatkan perempuan sebagai the second sex yang bahkan tercermin dalam ungkapan-ungkapan proverbial yang sangat mengunggulkan laki-laki (Fauzei dkk, 1993: 50). Dunia yang berkembang perlahan menghapus semua anggapan bahwa perempuan itu kurang berperan dalam kehidupan. Sekarang seluruh dunia sudah mengakui betapa besarnya peran perempuan dalam kehidupan, sama halnya dengan kaum laki-laki.

Pendapat tersebut didukung pernyataan bahwa laki-laki memiliki hak dan kewajiban terhadap perempuan dan sebaliknya perempuan juga memiliki hak dan kewajiban terhadap laki-laki (Fakih, 2007: 130). Dari pernyataan di atas, maka peran perempuan sangat diperlukan dalam 
dalam kehidupan baik dalam keluarga, masyarakat dan kegiatan lainya. Peran perempuan seharusnya memiliki hak dan kewajiban yang sama dengan kaum laki-laki. Terlebih lagi perempuan itu dianggap sebagai sosok yang lemah, pasrah, manja, tidak mempunyai ketegaran, keperkasaan, serta ketegasan. Akibatnya, perempuan selalu diposisikan dalam lapisan kedua setelah laki-laki.

\section{Metode Penelitian}

\section{A. Tempat dan Waktu Penelitian}

Lokasi penelitian ini di Desa Padang Pio Kecamatan Banyuke Hulu Kabupaten Landak Kalimantan Barat. Desa Padang Pio terletak di Kecamatan Banyuke Hulu Kabupaten Landak Provinsi Kalimantan Barat. Luas wilayah $529,5 \mathrm{~m}^{2}$ merupakan wilayah yang strategis dengan luas beberapa bagian areal perkebunan penduduk dan persawahan serta daratan sebagai tempat hunian warga.

Penelitian ini dilaksanakan selama 6 bulan yaitu mulai bulan Febuari sampai Juli 2016.

\section{B. Pendekatan dan Jenis Penelitian}

Pendekatan penelitian ini adalah metode kualitatif. Pendekatan kualitatif merupakan metode penelitian yang digunakan untuk meneliti pada kondisi obyek yang alamiah, dimana peneliti adalah sebagai instrumen utama, teknik pengumpulan data dilakukan secara trianggulasi, analisis data bersifat induktif, dan hasi penelitian kualitatif menekan pada makna (Sugiyono, 2014:1). Penelitian Kualitatif yang menekankan pada makna, lebih memfokuskan pada data kualitas dengan analisis kualitatifnya (Sutopo 2002: 48).

\section{Sumber Data}

\section{a) Sumber Data Primer}

Sumber data primer adalah sumber data penelitian yang diperoleh secara langsung dari sumber asli (tidak melalui perantara). Data primer berupa opini subjek (orang) secara individual dan kelompok, hasil observasi, kejadian, dan hasil pengujian (Amin, 2003 : 57). Menurut (Hasan 2004: 19), data primer adalah data yang diperoleh atau dikumpulkan langsung di lapangan oleh orang yang melakukan penelitian.

\section{b) Sumber Data Sekunder}

Sumber data sekunder adalah data penelitian yang diperoleh peneliti secara tidak langsung melalui media perantara (diperoleh dan dicatat atau laporan oleh pihak lain). Data sekunder umumnya berupa bukti, catatan atau laporan historis yang telah tersusun dalam arsip yang dipublikasikan dan yang tidak dipublikasikan (Amin, 2003: 57).

\section{c) Sampel dan Teknik Pengambilan Sampel}

Menurut (Amin 2003: 65) Teknik sampel adalah metode pengumpulan informasi (data terhadap sebagian anggota populasi). Teknik pengambilan 
sampel menggunakan snowball sampling. Dalam sampling ini kita mulai dengan kelompok kemudian berkembang pada kelompok lain yang berkait dan begitu seterusnya, sehingga jumlah informal semakin bertambah, bagaikan bola salju yang semakin membesar bila meluncur dari puncak bukit ke bawah (Nasution, 2011: 99).

\section{Teknik Pengumpulan Data}

\section{Wawancara}

Jenis wawancara yang dipilih oleh peneliti yaitu jenis wawancara bebas terpimpin mempersiapkan pokok-pokok pertanyaan yang menggunakan bahasan dan kalimat secara bebas. Proses wawancara dimulai dengan menyiapkan pokok-pokok pertanyaan yang akan diajukan kemudian dalam penyampaiannya menggunakan kalimat sendiri, selain itu tidak menutup kemungkinan mengajukan pertanyaanpertanyaan yang lain untuk memperoleh data yang lebih lengkap. Mengingat narasumber yang diambil adalah sebagian masyarakat Desa Padang Pio dengan tingkat pendidikan yang berbeda-beda maka jenis wawancara ini dipilih agar pelaksanaannya bersifat fleksibel.

\section{Observasi}

Observasi adalah metode pengumpulan data yang digunakan untuk menghimpun data penelitian melalaui pengamatan dan pengendiraan (Bungin, 2007: 115). Teknik observasi digunakan untuk menggali data dari sumber data yang berupa peristiwa, tempat atau lokasi dan benda serta tekanan gambar yang dilakukan secara langsung maupun tidak langsung.

\section{Dokumentasi}

Teknik pengumpulan data dengan dokumentasi ialah pengambilan data yang diperoleh melalui dokumen-dokumen (Usman dan Akbar, 2004: 72). Metode ini salah satu cara yang memudahkan dalam kegiatan penelitian, karena dalam melakukan penelitian harus ada sumber yang relevan dan mendukung sehingga penelitian yang dilakukan dapat berjalan lancar.

\section{E. Prosedur Penelitian}

Tahapan-tahapan penelitian sebagai berikut:

\section{Tahap Persiapan}

Tahap persiapan penelitian ini menyangkut penentuan tema dan pengajuan judul, pengamatan atau observasi awal. Kegiatan-kegiatan tersebut dilakukan pada bulan Februari. Setelah mendapat persetujuan mengenai tema dan judul penelitian dari dosen pembimbing, maka kegiatan selanjutnya adalah mengadakan pengamatan awal terhadap objek penelitian agar memperoleh gambaran tentang lokasi penelitian dan narasumber yang akan dijadikan informan untuk mendukung pelaksanaan penelitian.

\section{Tahap pelaksanaan}

Kegiatan yang dilakukan dalam tahap ini adalah pengumpulan data dari 
lapangan. Langkah awal untuk memperoleh data lapangan adalah mencari informasi dikantor desa agar memperoleh gambaran masyarakat, kemudian dilanjutkan dengan mencari informasi pada sejumlah informan yang relevan dengan asfek penelitian. Proses pencarian informasi menggunakan teknik snowball sampling sehingga dapat terus berkembang tidak hanya terpaku pada informan yang telah ditentukan sebelum adanya wawancara.

\section{Tahapan Penyelesaian}

Tahap penyelesaian ini berupa penyusunan laporan penelitian. Setelah temuan dapat dirumuskan dengan jelas, laporan disusun secara obyektif dan sistematis sesuai data yang ada, sehingga validitas hasil penelitian dapat tercapai dan tersusun hasil penelitian dapat tersaji dengan baik. Secara terperinci penelitian ini dapat diketahui melalui jadwal penelitian yang dimulai sejak pengajuan judul sampai dengan kegiatan akhir yaitu penyusunan hasil laporan penelitian yang telah melalui analisis dan berbagai revisi.

\section{F. Teknik Analisis Data}

Pengumpulan data merupakan jantung penelitian kualitatif dan analisisi data merupakan jiwanya. Analisis data adalah proses mencari dan menyusun secara sistematis data yang diperoleh dari hasil wawancara, catatan lapangan, dan dokumentasi, dengan cara mengorganisasikan data kedalam kategori, menjabarkan kedalam unit-unit, melakukan sintesa, menyusun kedalam pola, memilih mana yang penting dan mana yang akan dipelajarai, dan membuat kesimpulan sehingga mudah untuk dipahami diri sendiri maupun orang lain (Sugiyono, 2014: 93). Analisis data akan bergerak pada sub bagian yaitu Reduksi data, penyajian data dan verifikasi/simpulan.

\section{Pembahasan}

A. Pengertian Dan Fungsi Upacara Naik Dango Di Desa Padang Pio Kecamatan Banyuke Hulu Kabupaten Landak Kalimantan Barat

Tradisi upacara Naik Dango merupakan salah satu kebudayaan Dayak Kanayatn di Kalimantan Barat. Upacara Naik Dango ini salah satu warisan kebudayaan nenek moyang Dayak Kanayatn yang terus dikembangkan dan dilestariakan menjadi tradisi budaya adat Dayak Kanayatn. Kata "Dango" dalam bahasa Dayak Kanayatn yang berarti lumbung yaitu tempat atau gudang untuk menyimpan padi.

Naik Dango yang berarti menyimpan padi di Dango (lumbung), atau pesta Dayak dalam rangka ucapan syukur atas hasil panen padi. Sebuah tradisi tahunan yang rutin digelar setahun sekali yaitu pada tanggal 27 April setiap tahunnya yang dipimpin oleh seorang panyangahatn (Imam Adat) yaitu seorang yang dianggap mampu dan menguasai doa-doa maupun mantra- 
mantra. Upacara Naik Dango merupakan suatu upacara yang bagi masyarakat setempat sehingga dikategorikan upacara besar. Upacara ini diadakan pada tanggal 27 April setiap tahunnya (Widyanto, dkk 1997: 73).

Pendapat yang tidak jauh berbeda disampaikan oleh Timas, mengatakan Naik Dango diadakan rutin setahun sekali pada tanggal 27 April yang merupakan salah satu tradisi masyarakat suku Dayak Kanayatn. Naik Dango yang berarti menyimpan padi di Dango (Lumbung) atau pesta Dayak dalam rangka syukuran atas hasil panen padi yang akan dipersembahkan kepada Jubata (Tuhan).

Sebuah tradisi yang merupakan salah satu wujud syukur masyarakat terhadap Tuhan Yang Maha Esa atas hasil panen, kesehatan, dan bebas dari bencana. Melelui tradisi Naik Dango ini masyarakat Dayak Kanayatn percaya bahwa hasil padi yang mereka peroleh merupakan anugrah dan karunia yang diberikan Jubata (Tuhan), untuk itu masyarakat Dayak sangat menghormati dan menghargai padi. Untuk memperoleh padi butuh pengorbanan dan perjuangan yang dihadapi anatara Talino (Manusia) dan Jubata (Tuhan) sehingga terjadilah tragedi pengusiran dikeluarga antara manusia dan Jubata (Tuhan).

Setelah ditemukanya padi masyarakat Dayak Kanayatn tidak lagi makan kulat (Jamur) sebagai makanan pokok mereka karena sudah ada padi yang bisa mereka budidayakan. Tradisi Naik Dango ini berfungsi untuk mempereratkan rasa gotong royong serta kekeluargaan masyarakat, sekaligus juga berfungsi untuk melestarikan tradisi masyarakat setempat. Tujuan upacara Naik Dango sebagai rasa syukur masyarakat kepada Jubata (Tuhan) atas panen padi yang telah dipereoleh.

Menurut Bhari (Dalam Ivo 2001:293-294) Upacara Naik Dango berfungsi untuk menyukuri karunia Jubata (Tuhan), memohon restu kepada Jubata (Tuhan), memohon restu kepada Jubata (Tuhan) untuk menggunakan padi yang telah disimpan di Dango, pertanda penutupan tahun berladang, dan mempererat hubungan persaudaraan. Masyarakat percaya bahwa apabila tradisi tersebut tidak dilaksankan, masyarakat akan gagal panen dan padi tidak akan datang lagi dirumah mereka, selain itu desa mereka akan mendapatkan bencana.

Karena alasan itulah hingga saat ini masyarakat Desa Padang Pio masih melestarikan tradisi tersebut secara turun temurun. tradisi yang hingga saat ini masih dilestarikan masyarakat Dayak Kanayatn di Kalimantan Barat salah satunya adalah tradisi upacara Naik Dango. Naik Dango merupakan penutupan dari rangkaian upacara yang berkaitan dengan kegiatan berladang khususnya tanam padi, serta sebagai tanda bahwa kegiatan perladangan telah selesai dilaksankan. Salah satu tradisi tradisi masyarakat Dayak di Kalimantan 
Barat yang tidak hanya mengandung nilai fungsi magis spritual, tetapi juga mempunyai nilai fungsi sosial untuk mempererat hubungan antara manusia. Semakin maju dan berkembangnya jaman ternyata tidak menyurutkan semangat warga di Desa Padang Pio Kecamatan Banyuke Hulu Kabupaten Landak Kalimantan Barat untuk terus melestariskan salah satu tradisi upacara Naik Dango tersebut. Sebuah tradisi yang merupakan salah satu wujud syukur masyarakat terhadap Tuhan Yang Maha Esa terhadap hasil panen, serta untuk membersihkan Desa dari segala yang tidak diinginkan.

Tradisi upacara Naik Dango berfungsi sebagai upacara rasa syukur masyarakat Dayak Kanayatn terhadap hasil panen yang mereka peroleh, dan untuk mempererat rasa gotong royong serta kekekluargaan masyarakat, sekaligus berfungsi untuk melestarikan budaya masyarakat.

Menurut Bapak Saimin selaku seorang panyangahatn (Imam Adat) Naik Dango bertujuan untuk mempersembahkan hasil panen padi yang telah diperoleh selama setahun sekali kepada Jubata (Tuhan) atau ucapan rasa syukur masyarakat Dayak atas hasil panen padi, kesehatan, dan ketentraman,yang diselenggarakan dalam bentuk upacara ritual Naik Dango sebagai warisan nenek moyang. Selaian sebagai upacara ungkapan rasa syukur masyarakat Dayak Kanayatn
Naik Dango juga berfungsi sebagai sebgai media sosial untuk mempererat hubungan antara warga masyarakat, penunjang pariwisata untuk menarik wisatawan asing maupun lokal. Selain fungsi tersebut, terdapat juga nilai-nilai yang terkandung didalam upacara Naik Dango seperti nilai religi yang terkandung dalam upacara tersebut menggambarkan bagaimana masyarakat suku Dayak Kanayatn menempatkan Jubata (Tuhan) sebagai pusat dalam pengaturan kehidupan mereka. Nilai yang terkandung tersebut membawa masyarakat Dayak Kanayat lebih mengenal dan mensyukuri apa yang telah dimiliki, dan dapat hidup saling tolong menolong satu sama lainya.

B. Peran Perempuan Dalam Tradisi Upacara Naik Dango Di Desa Padang Pio Kecamatan Banyuke Hulu Kabupaten Landak Kalimantan Barat.

Dalam tradisi upacara Naik Dango di Desa Padang Pio Kecamatan Banyuke Hulu Kabupaten Landak Kalimantan Barat, pelaku utama dalam persiapanmaupun pelaksanaannya adalah laki-laki, sedangkan perempuan hanya sebagai pelaku kedua. Sebagai buktinya, yang berperan sebagai pemimpin dalam pelaksanaannya upacara Naik Dango tersebut adalah laki-laki. Persiapan maupun pelaksanaan dalam tradisi upacara Naik Dango tersebut melibatkan kaum perempuan mulai usia remaja 18 tahun sampai orang Dewasa (Profil Desa Padang Pio, 2015: 107). 
Perempuan hanya diberi tugas untuk mengerjakan peran sekunder yang berkaitan dengan tugas domestik seorang perempuan yaitu sebagai pembuat bahan untuk upacara Nyangahatn (Roba atau plantar), masakan untuk acara taun baru, sebagai penari Nimang Padi, Ngantar Panompo, dan Jonggan.

Dalam penelitian ini, peran perempuan dalam tradisi upacara Naik Dango dipisahkan dalam dua pembagian waktu, yaitu peran perempuan pada saat persiapan atau sebelum pelaksanaan upacara Naik Dango dan peran perempuan pada waktu pelaksanaan upacara Naik Dango.

1) peran dari kaum perempuan pada waktu persiapan atau sebelum pelaksanaan tradisi upacara Naik Dango di Desa Padang Pio, yaitu sebagai berikut:

a) Pembuat bahan Nyangahatn (Roba/ plantar)

Roba atau plantar adalah perlengkapan yang diperlukan/digunakan dalam acara selamatan dalam tradisi upacara Naik Dango muapun dalam tradisi lainnya. Penggunaan roba tersebut merupakan simbol atau pemikiran-pemikiran yang tidak terjangkau, sehingga dengan penggunaan roba tersebut mereka dapat mengekspresikan cara beribadah sesuai dengan kepercayaan masyarakat Dayak Kanayatan. Penggunaan roba atau plantar dalam kegiatan ritual Nyangahatan merupakan bagian dari simbol. Dalam pengenalan dan penggunaan simbol pada nasyarakat Dayak di Kalimantan Barat jelas terdapat banayk persamaan. Hal ini ada kaitannya dengan kepercayaan mereka, yang menganggap bahwa alam itu, baik yang nyata maupun yang gaib. Upacara Nyangahatn ini dipimpin oleh Panyangahatn (Imam Adat) yaitu laki laki berusia 60 tahun bahkan 70an yang memiliki kekuatan spiritual religi adat (Profil Desa Padang Pio, 2015: 107).

Berbagai macam sesaji atau roba yang terdapat dalam ritual Nyangahatn merupakan salah satu bentuk aktualisasi diri yang dilakukan semata-mata untuk mendekatkan diri dengan Jubata (Tuhan). Fungsi upacara adat nyangahatn terhadap kegiatan simbolis upacara untuk menolak segala macam roh jahat, meminta keselamatan dan kesembuhan, dan membayar kesalahan yang telah dilakukan. Upacara adat nyangahatn merupakan budaya religi asli adat Dayak Kanayatn dengan bahasabahasa adat suku Dayak Kanayatn. Nyangahatn sebagai bentuk penyampaian doa yang dilengkapi dengan berbagai macam perangkat dan perlengkapan adat, di dalam upacara adat nyangahatn dikenal dengan tiga istilah yaitu, pertama babamang merupakan doa yang tidak perlu 
menggunakan perlengkapan adat seperti sesaji akan tetapi cukup membaca doa saja. Kedua Basampakng merupakan makna sebagai rasa untuk menyatakan diri tunduk terhadap segala-galanya, atau disebut dengan kahula yang artinya mohon untuk direstui dan ditanggapi.

Tradisi Nyangahatn ini merupakan suatu tradisi atau upacara yang pada dasarnya adalah memohon kepada Tuhan agar hajatnya dilancarkan atau dipermudah. Hajat tersebut misalnya, agar diberi keselamatan, kesehatan, bebas dari bencana dan rasa syukur atas berkat, rejeki yang sudah kita terima. Melalui ritual Nyangahatn ini lah masyarakat Dayak percaya hasil bumi yang kita peroleh harus dikembalikan kepada Jubata (Tuhan) sebagai rasa syukur Masyarakat Dayak. Roba sangat diperlukan untuk proses nyangahatn, untuk itu kaum perempuanlah yang bertugas penuh dalam mempersiakan sesajen atau roba. Untuk mempersiapkan roba tersebut kaum perempuan berkumpul dirumah panjang (Rumah adat) untuk memasak didapur yang sudah tersediakan oleh warga.

Setelah bahan-bahan sesajen atau roba sudah siap barulah kaum laki-laki yang menata atau menyusun roba tersebut setelah robanya sudah siap kaum laki-laki yang bertugas membawanya ditempat khusus untuk ibadah secara adat dan yang akan dipimpin oleh imam adat panyangahatn yang berusia kurang lebih 60 tahun yang memiliki kemampuan khusus ilmu spiritual religi dalam bentuk upacara keagamaan adat Dayak Kanayatn.

Berikut ini adalah beberapa macam jenis isi roba yang biasanya terdapat dalam upacara adat Naik Dango beserta maknanya yang terkandung di dalamnya:

1) Babi

Babi merupakan perlengkapan utama dalam upacara adat Dayak Kanayatn tanpa adanya seekor babi maka upacara adat tidak bisa dilaksanakan. Babi sendiri memiliki arti dan makna khusus dalam upacara adat atupun ritual kegiatan keagamaan buadaya Dayak Kanayatn lainya. Babi melambangkan hukum adat yang perlu ditegakkan karena apabila sudah menggunakan babi berarti sudah lengkap acara tersebut. Masyarakat Dayak Kanayatn menganggap bahwa babi merupakan hewan yang suci, maka dari itu babi selalu digunakan dalam kegiatan adat istiadat masyatarakat Dayak baik dalam kegiatan upacara adat lainya. Babi merupakan hewan yang sakral dan memiliki kekuatan, keberanian dan kehidupan dalam adat istiadat. Selain itu babi juga digunakan sebagai syarat menuju kehidupan baru. Dalam kegiatan upacara nyangahatn babi 
dilambangkan sebagai lambang pengorbanan masyarakat Dayak dengan tujuan akan dipersembahkan kepada Jubata (tuhan) sebagai rasa balas budi, bayar niat (kesalahan) ataupun sebagai rasa syukur masyarakat Dayak Kanayatn kepada Jubata (Tuhan). Jika tidak ada kurban seekor babi maka masyarakat mempunyai hutang kepada Jubata (Tuhan), maka dari itu segala hutang kepada Jubata harus dibayar lunas dengan cara mengorbankan seekor babi hitam. Sebelum memotong babi pun diadakan ritual nyangahat yaitu ritual bapinta atau bapadah dengan tujuan supaya acara yang akan dilaksanakan dapat berjalan dengan lancar, selain itu bertujuan supaya bagi yang bertugas didapur dalam memasak dapat diberikan kesehatan, keselamatan, dan apa yang diperlukan dalam urusan dapur dapat tercukupi dan terpenuhi.

Setelah acara pemotongan babi sudah selesai barulah memilih bagian daging yang akan digunakan untuk upacara selanjutnya yaitu upacara Naik Dango. Babi yang digunakan untuk kurban persembahan adalah babi hitam jantan sebesar 30-40 kg merupakan persembahan irisan-irisan daging babi disebut galumakang (sekumpulan irisan bagian daging babi). Daging babi yang dijadikan galumakang diantaranya, kulit/ lamak (kulit/ lemak punggung, selebar 4 jari), apo (lemak bagaian perut), angkakng (rusuk), pengekng ( tulang pinggul), amali (kulit ketiak kiri), padar ( rusuk, hati, dan kura), dan galompa (kulit berlemak 4 bungkus). Bagian-bagain irisan daging babi inilah yang nantinya akan digunakan dalam upacara Naik Dango.

2) Ayam

Ayam memiliki tujuan agar segala sesuatu yang telah dilunturkan, dilarutkan supaya diterbangkan jauh dari keluaraga dan lingkungan dan dikuburkan sebagai matahari yang terbenam ke arah barat. Setelah doa disampaikan ayam disembelih dan diambil darahnya untuk melengkapi kurban, ayam dibersihkan hanya membuang usus. Ayam kurban yang selanjutnya dipanggang atau direbus dengan bentuk dada terbelah.

Ayam berfungsi sebagai bentuk pengorbanan kita, atau sebagai kurban. Biasanya ayam yang digunakan adalah seekor ayam jantan atau ayam jago dan ayam betina berwarna putih, masyarakat Dayak Kanayatn bisanya menyebut dengan ayam selasih. Ayam melambangkan kemakmuran, sebab ayam selalu terbang bebas dan dapat mencari makan sendiri.

3) Beras ketan (pulut) 
Berasa ketan (pulut) sebagai lambang persatuan adat dan tekat kuat untuk menegakkan kebenaran. Beras yang digunakan dalam upacara Naik Dango beras ketan hasil panen dengan tujuan sebagai persembahan kepada Jubata (Tuhan). beras ketan dipilih sebagai bahan perlengkapan sesaji upacara karena dianggap mampu mempererat tali persaudaraan, kesatuan dan rasa kekeluargaan.

4) Beras biasa

Beras biasa sebagai pelantar (bakal pelengkap hidup) adat artinya harus ada bakal hidup dikemudian hari. Beras ini sebagai simbol bahwa manusia diharuskan mempunyai simpanan atau persiapan untuk masa yang akan datang. Beras juga merupakan sumber kehidupan, maka dari itu masyarakat Dayak Kanayatn percaya bahwa jangan pernah berbicara kotor kalau didepan beras dan harus menghormati beras sebagaimana kita menghormati manusia. Beras biasa ini meruapkan hasil pertanian masyarakat Dayak Kanayatn untuk dipersembahkan kepada Jubata (Tuhan).

5) Beras basah

Beras basah berfungsi mencuci atau menghilangkan segala sesuatu atau kekotoran yang melekat pada manusia. Beras basah ini campuran antara beras ketan dan beras biasa yang akan digunakan dalam upacara. Terlebih dahulu beras ini dibersihkan sampai bersih, dan nantinya akan digunakan untuk upacara dengan tujuan sebagai persembahan.

6) Beras kuning

Beras kuning berfungsi sebagai peluntur, pelarut segenap hal yang kurang berkenan dan berperan sebagai tudung, dinding penyekat dan benteng dari segala gangguan atau sebagai lambang kebersihan adat. Beras kuning ini berasal dari beras biasa. Dikatakan beras kuning karena beras ini berwarna kuning setelah dicampurkan dengan kunyit sebagai pewarna. Tujuannya untuk menghilangkan segala hal yang tidak diinginkan dan membersihkan segala penyakit.

7) Baras banyu (beras yang diberi minyak)

Baras banyu (beras yang diberi minyak) sebagai lambang persalinan raja kepala adat. Baras banyu juga melambanagkan persaudaraan adat Dayak Kanayatn. Baras banyu berasal dari beras ketan dengan dicampur sedikit minyak kelapa. Dalam upacara adat baras banyu digunakan untuk menyambut kedatangan tamu dan tanda penghormatan kepada tamu atau para undangan.

8) Sekapur sirih (topokng) 
Sekapur sirih (topokng) didalamnya ada pinang, daun sirih, kapur sirih, rokok, dan tembakau berfungsi sebagai bentuk adat ramah tamah atau sebagai pembukaan cerita. Sekapur sirih merupakan makanan bagi ibu-ibu maupun kaum laiki-laki. Biasnya selama menimkati sekapur sirih ini masyarakat Dayak merasa senag karena bisa berkumpul bersama warga dan masyarakat sekitarnya untuk saling berbagi cerita. Didalam sekapur sirih terdapat beberapa bahan yaitu, pertama pinang melambangkan keturunan orang yang baik budi perkerti, jujur, serta memiliki derajat tinggi. Bersedia melakukan pekerjaan dengan hati terbuka dan bersungguh-sungguh. Makna ini berdasarkan dari sifat pohon pinang yang tinggi lurus ke atas serta mempunyai buah yang lebat dalam satu tandan. Kedua kapur berasal dari karang atau batu kapu, berwarna putih bersih dan memiliki rasa payau yang dilambangkan dengan sifat hangat, hati nyang bersih, dan melunakkan hati yang keras. Ketiga daun sirih, memiliki lambang sifat rendah hati, memberi, serta memuliakan orang. makna ini ditafsirkan dari cara tubuh sirih yang memanjat pada para-para atau batang pohon tanpa merusak tempatnya hidup. Keempat rokok daun, yang melambangkan kehangatan dan rasa peduli terhadap orang lain.

9) Gambir

Gambir memiliki rasa pahit melambangkan kecelakaan atau keteguhan hati. Warna ini diperoleh dari warna daun gambir kekuningkuningan yang artinya bahwa sebelum mencapai sesuatu kita harus bersabar dalam melakukan proses untuk mencapainya.

10) Buah Tengkawang

Buah tengkawang melambangkan kejayaan, kemakmuran, dan kemenangan. Tengkawang ini juga sebagai lambang tanda panen padi segera dimulai. Buah tengkawang memiliki makna penting dalam upacara Naik Dango, karena buah tengkawang ini berasal dari Jubata (Tuhan) yang bertujuan sebgai obat dari segala penyakit. Buah tengkawang juga melambangkan identitas suku Dayak Kanayatn .

11) Cucur (tumpi)

Cucur (tumpi) lambang masakan adat dari kaum perempuan. Cucur (tumpi) yang digunakn dalam upacara Naik Dango terdapat dua rasa yaitu, pertama tanpa rasa (tawar) tanpa ada pewarna yang melambangkan kesucian bagi kaum perempuan artinya seorang perempuan harus hidup benar, jujur, dan berbuat baik di dalam masyarakat adat. Tumpi/cucur 
melambangkan kesatuan atau semangat yang satu dari seluruh warga masyarakat.

Kedua cucur manis yang diberi gula jawa yang melambangkan pahit manis kehidupan yang dijalankan, maka dari itu seorang perempuan harus hidup sabar, iklas dan tetap semangat dalam menjalankan kehidupan.

12) Daun selasih dan air.

Air yang digunakan diambil dari sungai sebagai lambang penyuci kesejukan hidup. digunakan sebagai pengudusan terhadap berbagai hal yang kurang berkenan selama kegiatan berlangsung, dengan menggunakan lambang bujakng pabaras (laki-laki perkasa). Daun selasih dan air ini nantinya akan ditaruh di dalam gelas kemudian seorang panyangahatn (imam adat) nanti akan memercik berkali-kali air tersebut kepada anggota masyarakat yang menghadirkan upacara adat.

13) Telur

Telur sebagai lambang kebulatan mufakat adat dan melambangkan adanya kehidupan baru. telur yang dipilih yaitu telur ayam kampung. Biasanya telur yang digunakan dalam upacara Naik Dango telur yang sudah matang dan telur yg belum matang. Telur yang sudah matang bertujuan sebagai persembahan sesaji makan roh-roh jahat dan para leluhur nenek moyang. Sedangkan telur yang belum matang digunakan sebagai perlengkapan bahan upacara yang memiliki makna bahwa telur melambangkan kehidupan baru yang akan dijalankan.

14) Lemang atau poe

Lemang/ poe sebagai lamabang masakan adat dari kaum laki-laki. Dalam upacara adat lemang selalu wajib digunakan, untuk membuatnya pun selalu melibatankan pihak lakilaki karena dianggap laki-lakilah yang bisa untuk membuatnya. Bahan yang perlu disiapkan untuk membuat lemang, yaitu, bambu borok (bambu yang memiliki kulit tipis) dan bambu yang digunakan bambu yang masih muda. Selain bambu bahan yang digunakan daun pisang yang masih muda, beras ketan, santan, garam sebagai penambah rasa. Daun pisang nantinya akan dimasukan kedalam bambu, setelah itu barulah beras ketan dan disirami dengan santan, setelah itu lemang ini akan dimasak dengan cara dibakar dengan menggunkaan kayu bakar dengan disusun bentuk barisan memanjang.

15) Tungkat atau pulut

Tungkat atau pulut yang dimasak dalam bambu panjang dan diberi lubang tengah (tongkat) sebagai lambang tongkat adat atau sebagai pusat adat. Telur masak 
melambangkan persatuan dan sulit untuk dipisahkan sehingga dapat digunakan untuk menolak segala ancaman dari dalam maupun dari luar. Tungkat atau pulut ini hampir sama dengan lemang karena prosesnya sama-sama dibakar. Perbedaanya hanyalah pada beras yang digunakan adalah beras campuran antara beras biasa dan beras ketan, kemudia berasnya dicampur sedikit darah babi sebgai pewarna masakan dan untuk memasaknya pun tidak menggunakan daun pisang.

16) Minyak/langgir

Minyak/langgir terbuat dari langgir dicampur minyak kelapa melambangkan pelantru penawar peluntur segala yang tidak baik dalam kehidupan. minyak atau alnggir ini digunakan untuk memberi kesembuhan pada masyarakat yang mengadakan upacara Nyangahatn, dengan cara nantinya akan dioleskan di kening pada masyarakat yang menghadiri upacara tersebut yang dipimpin oleh panyangahatn (Imam Adat)

17) Padi

Padi merupakan tanaman yang sangat diagung-agungkan oleh masyarakat Dayak, karena padi membawa kejayaan bagi masyarakat Dayak Kanayatn. Menurut masyarakat Dayak
Kanayatn padi dianggap sebagai manusia dalam ajaran keagamaan suku adat Dayak, untuk memperolehnya pun tidaklah mudah, padi merupakan pemberian Jubata (Tuhan) yang diberikan kepada Manusia sebagai penganti kulat (jamur) untuk makanan pokok mereka. Hingga sampai saat ini masyarakat Dayak menjaga, menghormati, dan melestarikan padi sebagai mana mereka menghormati manusia.

18) Kopi dan gula

Kopi dan gula yang melambangkan segala keburukan pada manusia segera dihilangkan. Biasanya orang Dayak menggunakan kopi hitam dan gula pasair kemudia kopi tersebut dihidangkan kedalam secangkir gelas sebagai pelengkap ritual adat keagamaan. Kopi tersebut nantinya akan dipersembahankan kepada awa pama (roh nennek moyang).

19) Tepung tawar

Tepung tawar merupakan permohonan agar jubata menawarkan semua hal yang tidak berkenan. Permohonan ini disimbolkan dengan prilaku mengoleskan tepung tawar dikening atau telapak tangan keluarga pelaksana. Biasanya tepung tawar yang digunakan terbuat dari beras ketan.

20) Bontokng 
Bontokng (beras yang dibungkus pakai daun layakng (daun layang) dan dimasak didalam bambu, sebagai ungkapan janji yang disepakati bersama.

21) Uang logam

Uang logam digunakan sebagai lambang mata adat. uang logam digunakan sebagai mata adat dalam upacara artinya uang logam berfungsi untuk membayar adat selama upacara baik dimata masyarakat amaupun dimata Jubata(Tuhan). dengan cara demikian tidak lagi hutang antara masyarakat dan Jubata (Tuhan). selain digunkan sebagai lambang adat uang logam juga difungsikan sebagi lambang menolak kejahatan dari rohroh yang tidak diinginkan dan dikatakan mampu mengusir segala roh-roh jahat yang ingin menganggu.

22) Nyalipa

Nyalipa (dupa atau bunga harum), sebagai lambang pengharum adat. Nyalimpa digunakn untuk perlengakapn bahan sesaji dengan tujuan memberikan keharuman dalam upacara adat.

23) Paku

Paku melambangkan keberania dan sebagai perlindungan dari roh-roh jahat. Paku inni digunkan untuk melindungi masyarakat dari roh-roh yang tidak diinginkan dan biasanya digunakn sebagai pembukaan upacara.

24) Pelita

Pelita sebagai lambang terangnya hidup dalam adat. pelita ini digunakn untuk penerangnya jalan kehidupan seseorang. Padaa saat diadakan upacara adat pelita diarti sebagi penerangnya jalan upacara supaya acara tersebut berjalan dengan lancar. Selian itu pelita digunakan sebagai penerang untuk mencari jalan hubungan doa antara seorang panyangatn (Imam Adat) dan Jubata (Tuhan) supaya ritual tersebut diberikan jalan terang.

25) Kobet

Kobet (berupa sesajen dalam jumlah sedikit yang ditaruh dilayakng (mangkok) yang dicampur dengan darah ayam, cucur, pulut, lontong, garam dan telur (daun layang). Kobet sebagai lambang sosial masyarakat adat. Didalam kobet terdapat lima macam kobet yaitu, pertama kobet rayah sebagai lambang makan bersama, kedua kobet jajo sebagai lambang apabila dapat makanan maka harus dibagi-bagi, ketiga kobet panampe sebagai lambang untuk memberi makan tamu yang datang, keempat kobet pangamat (kobet pengaman) sebagai lambang persiapan rumah tangga, dan kelima kobet badarah (kobet berdarah) 
sebagai lambang perjuangan adat yang melahirkan keberanian dan ketegasan dalam adat.

Perlengkapan yang digunakan dalam upacara Nyangahatn yang nantinya akan disusun kedalam pahar (Nekara dari tembaga) dengan jumlah bahanbahan yang sudah ditersdiakan, maka jadilah sebuah roba atau plantar yang siap untuk melakukan ritual upacara adat Naik Dango. Dalam mempersiapkan bahan-bahan tersebut perempuanlah yang bertugas penuh dalam hal masak memasak. Selain bertugas untuk mempersiapkan bahan-bahan untuk persiapan ritual perempuan juga bertugas memasak makanan didapur untuk persiapan acara taun baru (pesta padi). Kegitan taun baru ini melambangkan kekeluargaan, persaudaraan, pada saat inilah terjalin silahturahmi antar masayarakat dan warga lainya. Kegiatan taun baru ini semua warga berkumpul dirumah adat untuk menikmati makanan yang sudah disediakan. Dan biasanya mereka duduk berbentuk lingkaran.

b) Taun Baru (Pesta Padi)

Acara taun baru (pesta padi) atau selamatan dilakukan di rumah panjang (rumah adat). Taun baru merupakan pesta Naik Dango atau acara selamatan, dimana dalam acara ini semua warga berkumpul dirumah adat Dayak
Kanayatn yaitu di Rumah Panjang untuk bersilahturahmi dan ramah tamah, pada saat ini lah terjalin hubungan kekeluargaan masyarakat Dayak Kanayatn. Dari acara taun baru ini semua warga mempersiapkan masakanmasakan serta makanan khas Dayak Kanayatn untuk dinimkati nantinya bersama para undangan dan kerabat keluarga.

Dalam acara taun ini perempuan bertugas untuk mempersiakan masakan yang akan dihidangkan seperti, Nasi berkat, sayuran, lauk pauk, Tumpi (cucur), lemang (pulut), kue lepet, dange dan jajanan lainnya. Masakan-masakan ini nantinya akan dihidangkan diruangan tamu dalam acara taun baru atau selamatan dengan tujuan bersilahturahmi dan saling mendoakan supaya hasil panen selama satu tahun ini diberkati dan kebiasaan adat Dayak Kanyatan yang selalu berbagi, memberi kepada orang lain.

Makan-makanan yang sudah disediakan oleh kaum perempuan ini harus dihabiskan dan tidak boleh tersisakan. Jika masaih ada sisanya nantinya akan dibawa pulang dan dibagikan kepada masyarakat lainnya. Para undangan yang hadir akan diberikan beras, daging babi, lemang, dan jajanan lainnya karena tradisi Masyarakat Dayak Kanayatn jika ada tamu pasti wajib membawa beras pulang 
kerumahnya meskipun hanya sedikit. Kegiatan taun baru ini dilaksankan pada siang hari. Dalam tradisi upacara Niak Dango setelah mengadakan acara selamatan taun Baru selesai maka diadakanlah juga pameran seperti, kerajian anyaman, perehiasan terbuat dari manik-manik, pakaian adat, makanan khas Dayak, dan lain sebagainya. Tujuannya untuk memperkenalkan kebudayaan Dayak Kanayatn di masyarakat luar serta melestarikannya.

\section{Peran Perempuan Pada Waktu} Pelaksanaan Tradisi Upacara Naik Dango Di Desa Padang Pio Kecamatan Banyuke Hulu Kabupaten Landak Kalimantan Barat.

Peran perempuan yang terlibat dalam pelaksanaan tarian-tarian tersebut berusia remaja 18 tahun sampai usia orang dewasa 30 tahun (Profil Desa Padang Pio, 2015: 107). Tarian-tarian tersebut pun memiliki arti dan makna khusus. Pentas seni tarian sangat wajib untuk ditampilkan dalam upacara Naik Dango. Upacara ini memiliki makna penting bagi masyarakat Dayak. Tarian tradisional tersebut merupakan warisan kebudayaan nenek moyang suku Dayak Kanayatn (wawancara Supiana dan Thomas 28 april 2016). Adapun jenisjenis tarian yang ditampilan pada saat upacara Naik Dango yaitu :

1. Tari Nimang padi
Tari Nimang Padi merupakan tarian untuk mendoakan padi agar panen selanjutnya lebih baik. Tarian ini melambangkan persembahan padi kepada Jubata (Sang Pencipta). Tari Nimang Padi dilaksanakan setelah padi didoakan oleh panyangahatn (Imam Adat), penampilan tarian ini dilaksankan siang hari.

Dalam acara kegiatan tarian ini, perempuan yang bertugas mengisi kegiatan tersebut. Jumlah penari dalam acara nimang padi berjumlah sekitar 6-7 orang. penari tersebut adalah gadis-gadis yang masih muda, dengan tujuan bahwa yang serang gadis dianggap masih suci dan mereka akan menari untuk mempersembahkan padi tersebut kepada Jubata (tuhan). Pakaian yang digunakan adalah pakaian adat Dayak Kanayatn. Tarian itu merupakan tarian manifestasi syukur kepada Jubata (Tuhan) atas keberhasilan petani memperoleh panen padi yang cukup memuaskan.

\section{Tari Ngantar Panompo}

Tari ngantar panompo melambangkan persaudaraan antar suku Dayak untuk saling membantu. Panompo yang berarti Upeti. Tarian ini dilaksanakan setelah barang-barang upeti di doakan untuk diantarkan kepada ketua Adat, setelah itu di simpan kedalam Dango atau lumbung padi. 
Tarian Ngantar Panompo dilaksanakan pada sore hari dan sering digunakan sebagai penutupan upacara Naik Dango. Tarian ini diciptakan oleh leluhur masyarakat Dayak Kanayatn berdasarkan pengalaman hidup dan ungkapan perasaan mereka pada masa lalu. Tari ngantar panomp bertujuan untuk mengantarkan upeti kepada tuan rumah yang mengadakan upacara adat Naik Dango. Dalam acara ini jumlah penari sekitar 20-25 orang baik perempuan maupun laki-laki yang memiliki tugas masing-masing. Perempuan pada umumnya bertugas sebagai membawa upeti yang sudah dipersiapkan, setelah sampai di Dango (Lumbung) perempuan juga yang menyerahkan padi tersebut untuk disimpan di Dango dan akan didoakan oleh panyangahatn.

\section{Seni tari Jonggan}

Tarian Jonggan melambangkan kebahagiaan, kegembiraan, dan mempersembahkan rasa syukur masyarakat kepada Jubata (Sang Pencipta). Menurut (Kristova, dkk, 2016: 7) mengatakan Tarian Jonggan ini sebagai ungkapan kegembiraan masyarakat dan sangat dikenal karena menjadi satu-satunya hiburan yang ada di masyarakat Dayak Kanayatn. Tarian Jonggan ini merupakan penutup yang bertanda bahwa rangkaian upacara Naik Dango sudah selesai.
Tarian Jonggan ini dilaksankan pada malam hari sebagai acara hiburan masyarakat setempat. Jumlah penari jonggan semuanya perempuan berjumlah sekitar 7-8 orang. Tari Jonggan adalah tari tradisional khas Dayak Kanayatn yang bersifat menghibur dan melambangkan suka cita dan kebahagiaan masyarakat Dayak Kanayatn.

Pada masa lampau Jonggan lebih sering ditarikan diacara syukuran, namun pada saat ini tari Jonggan lebih sering ditarikan diacara hiburan. Tari Jonggan juga menjadi media komunikasi yang baik dan biasa diambil pesannya dalam setiap pantun-pantun yang terdapat dalam syair lagu Jonggan bagi kehidupan masyarakat. selain menjadi media komunikasi, penari juga bisa menyalurkan bakatnya dalam menari dan menyannyi.

Dalam tarian ini perempuanlah yang bertugas sebagai penari yang berjumlah sekitar enam samap tujuh orang. Biasanya penari perempuan pada tarian Jonggan di sebut sebagai We'Jonggan yang artinya adalah penari Jonggan. Citra penari perempuan dalam sebuah pertunjukan tari merupakan sosok penebar pesona keindahan. Karena aura dan pesona keindahan merupakan kodrat yang telah diberikan Sang Pencipta kepada sosok perempuan. 
Sama dengan halnya dengan $W e^{\prime}$ Jonggan (penari Jonggan), penampilan secara fisik dan penampilan diatas panggung sangatlah diperhatikan bukan hanya sebagai hiburan tetapi makna dan nilai yang terkandung. Wanita yang menjadi penari Jonggan biasanya berpenampilan cantik, sehingga bisa dengan mudah menarik perhatian penonton. Selain itu, penari Jonggan juga dituntut harus kuat secara fisik, karena pementasan Jonggan ini biasnaya dilakukan bermalam-malam sampai para penonton sepi. Keberadaan tarian ini dapat memberi hiburan pada masyarakat Dayak Kanayatn.

\section{Penutup}

Peran perempuan dalam persiapan dan pelaksanaan tradisi upacara Naik Dango. Adapun peran dari perempuan, yaitu: Pembuat bahan Nyangahatn (Roba/Plantar); Pembuat bahan taun baru (Pesta Padi); dan Pentas Kesenian Rakyat.

\section{Daftar Pustaka}

Abdullah, Irwan. 2001. Seks, Gender dan Refroduksi Kekuasaan. Yogyakarta:Tarawang Press.

Bamba, John. 2008. Muzaik Dayak: Keberagaman Subsuku dan Bahasa Dayak di Kalimantan Barat. Pontianak: Institut Dayakologi.

Bungin, Burhan. 2007. Penelitian Kualitataif: Komunikasi, Ekonomi, Kebijakan Publik, dan Ilmu Sosial Lainnya. Jakarta: Kencana Prenada Media Grup.
Esten Mursal. 1999. Kajian Transformasi Budaya dalam. Bandung: Angkasa.

Fakih, Mansour. 2007. Analisis Gender dan Transformasi Sosial. Yogyakarta: Pustaka Pelajar.

Florus, Paulus, dkk. 2012. Kebudayaan Dayak: Aktualisasi dan Transformasi. Pontianak: Institut Dayakologi.

Haikal, Husain. 2012. Wanita Dalam Pembinaan Karakter Bangsa. Yogyakarta: Pustaka Pelajar.

Hanif. M. dkk. 2014. Agastya Jurnal Sejarah dan Pembelajaran: Peran Perempuan dalam Tradisi Upacara Bersih Desa (hlm. 23-24). Madiun: Prodi Pendidikan Sejarah IKIP PGRI Madiun.

Hanif. M. Dkk. 2013. Agastya Jurnal Sejarah dan Pembelajaran: Peran Perempuan dalam Perkembangan Ekonomi di Kelurahan Lembah Kecamatan Babatan Kabupaten Ponorogo (hlm. 259). Madiun: Prodi Pendidikan Sejarah IKIP PGRI Madiun.

Hasan Iqbal. 2004. Analisis Data Penelitian dengan Statistik. Jakar ta: PT Bumi Aksara.

Ivo, Herman. 2001. Gawai Dayak Fanatisme Rumah Panjang Sebagai Penelusuran Identitas (hlm. 293294). Pontianak: Universitas Tanjungpura.

Koentjaraningrat. 2009. Pengantar Ilmu Antropologi. Jakarta: PT Rineka Cipta.

Kristova, Yovi, dkk. 17 April 2016. Analisis Fungsi Tari Jonggan pada Suku Dayak Kanayatn Kabupaten Landak. E-mail (yovik@@yahoo.co.id). Pontianak: 
Program Studi Pendidikan Seni Tari dan Musik Universitas Tanjungpura.

Kusni, Andriani S. 2011. Budaya Dayak: Permasalah dan Alternatifnya. Pontianak: Institut Dayakologi.

Kusni. J.J. 2001. Negara Etnik. Beberapa Gagasan Pemberdayaan Suku Dayak. Yogyakarta: FuSPAD.

Miles, M.B dan Huberman, A.M. 1992. Analisis Data Kualitatif: Buku Sumber Tentang Metode-Metode Baru. Terjemahan oleh Rohidi, T.R. Jakarta: Universitas Indonesia Press.

Mintosih, dan Widyanto, Y. Sigit. 1997. Tradisi dan Kebiasaan Makan pada Masyarakat Tradisional di Kalimantan Barat. Jakarta: CV: Putra Sejati Raya.

Mosse. J. P. 2002. Gender dan Pembangunan. Yogyakarta: Pustaka Pelajar.

Moleong, J, Lexy. 2012. Metodologi Penelitian Kualitatif: Edisi Revisi. Bandung: PT Remaja Prosdakarya Offset.

Mulyadi, Silverius. 2011. Kamus Bahasa Dayak Kanayatn. Pontianak: D\&L Digital.

Mely G.T. 2004. Perempuan dalam Wacana Politik Orde Baru. Jakarta: Pustaka LP3ES Indonesia.

Nasution, S. 2011. Metode Research: Penelitin Ilmiah. Jakarta: PT Bumi Aksara.

Nazir, Moh. 2009. Metode Penelitian. Bogor: PT. Ghalia Indonesia.

Nurmawati, Ella. 2013. Kajian Folklor Upacara Adat Saparan Pundhen Joko Kasihan di Desa Cacaban Kidul Kecamatan Bener Kabupaten Purworejo. Forum Penelitian
Upacara Adat, 02 (2): 66-76: Universitas Muhammadiyah Purworejo.

Purwadi. 2005. Upacara Tradisional Jawa: Mengali Untaian Kearifan Lokal. Yogyakarta: Pustaka Pelajar.

Pusat Pembinaan dan Pengembangan Bahasa. 1999. Kamus Besar Bahasa Indonesia Edisi ke2. Jakarta: Departemen Pendidikan dan Kebudayaan Balai Pustaka. (hlm. 1108).

Rufinus. A. 2004. Dayakologi: Jurnal Revitalisasi dan Restitusi Budaya Dayak. Dalam Rufinus (Ed.), $N e^{\prime}$ Baruankng Kulup: Tema dan Pesan (hlm. 43). Pontianak: Mitra Kasih.

Rizal, Fauzie. 1993. Dinamika Gerakan Perempuan di Indonesia. Yogyakarta: PT Tiara Wacana Yogya.

Saryana, dkk. 2003. Upacara dan Rumah Adat: Suku Dayak dan Melayu di Kalimantan Barat. Pontianak: Romeo Grafika.

Setyadi, Elly M, dkk. 2007. Ilmu Sosial dan Budaya Dasar. Jakarta: Kecana Prenada Media Grup.

Sosro Dihardjo, Soedjito. 1991. Transformasi Sosial: Menuju Masyarakat Industri. Yogyakarta: PT Tiara Wacana Yogya.

Suardi, dkk. 17 April 2016. Struktur dan Nilai Budaya Nyangahatn Baburukng pada Upacara Adat Perladangan Dayak Kanayatn Kalimantan Barat.E-mail (ahe_sidas_63@yahoo.com). Pontianak: Program Magister Pendidikan Bahasa Indonesia Universitas Tanjungpura.

Sugihastuti dan S. Itsna Hadi. 2007. Gender dan Inferioritas Perempuan: Praktik 
Kritik Sastra Peminis. Yogyakarta: Pustaka Pelajar.

Sugiyono. 2008. Metode Penelitian Kuantitatif Kualitatif dan $R \& D$. Bandung: CV Alfabeta.

Sugiyono. 2014. Memahami Penelitian Kualitatif. Bandung: CV Alfabeta.

Sutopo, B. H. 2002. Metodologi Penelitian Kualitatif: Dasar Teori dan Terapannya dalam Penelitian. Surakarta: Sebelas Maret University Press.
Silalahi, A.G. 2003. Metodologi Penelitian Studi Kasus. Sidoarjo: Mitra.

Suyono, Ariyono. 1985. Kamus Antropologi. Jakarta: Akademika Prressindo.

Tindarika, Regaria. 2015. Fungsi Tari Ngantar Panompo dalam Upacara Adat Naik Dango pada Suku Dayak Kanayatn. Pontianak: Program Studi Pendidikan Seni Tari dan Musik Universitas Tanjungpura.

Usman, Husaini. 2004. Metodologi Penelitian Sosial. Jakarta: PT Bumi Aksara 